\title{
The Structure and Composition of Holocene Coral Reefs in the Middle Florida Keys
}

By Lauren T. Toth, Anastasios Stathakopoulos, and Ilsa B. Kuffner

Open-File Report 2016-1074

U.S. Department of the Interior

U.S. Geological Survey 


\title{
U.S. Department of the Interior \\ SALLY JEWELL, Secretary
}

\author{
U.S. Geological Survey \\ Suzette M. Kimball, Director
}

U.S. Geological Survey, Reston, Virginia: 2016

For more information on the USGS-the Federal source for science about the Earth, its natural and living resources, natural hazards, and the environment-visit

http://www.usgs.gov/ or call 1-888-ASK-USGS (1-888-275-8747).

For an overview of USGS information products, including maps, imagery, and publications, visit http://www.usgs.gov/pubprod/.

Any use of trade, firm, or product names is for descriptive purposes only and does not imply endorsement by the U.S. Government.

Although this information product, for the most part, is in the public domain, it also may contain copyrighted materials as noted in the text. Permission to reproduce copyrighted items must be secured from the copyright owner.

Suggested citation:

Toth, L.T., Stathakopoulos, Anastasios, and Kuffner, I.B., 2016, The structure and composition of Holocene coral reefs in the Middle Florida Keys: U.S. Geological Survey Open-File Report 2016-1074, 27 p. http://dx.doi.org/10.3133/ofr20161074.

ISSN 2331-1258 (online) 


\section{Contents}

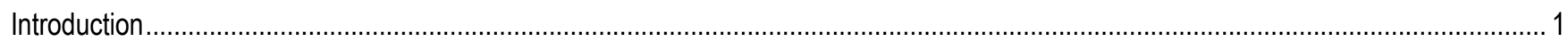

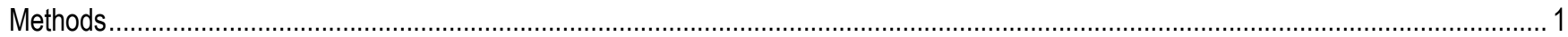

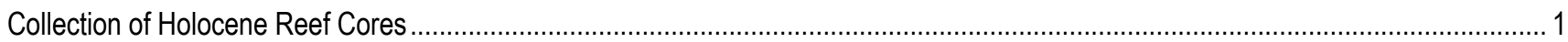

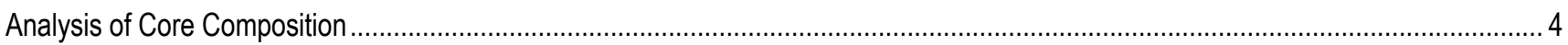

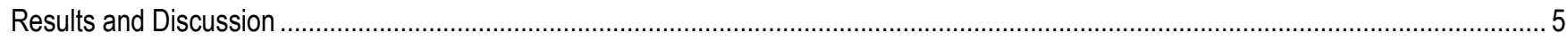

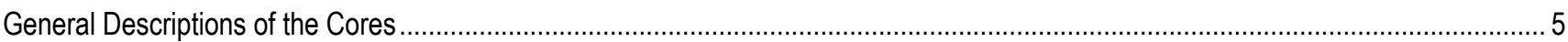

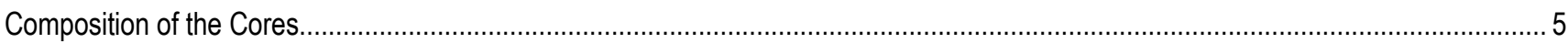

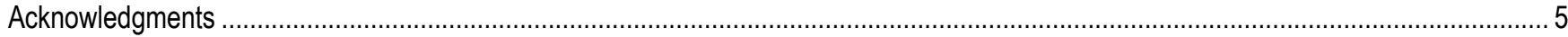

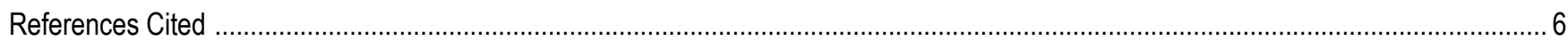

Appendix 1. Photographs and Descriptive Logs of Holocene Reef Cores from the Middle Florida Keys .......................................... 7

\section{Figures}

1. Map of the Florida Keys showing the location of the coring sites in the Middle Keys sector: Sombrero Reef, Tennessee Reef, and Alligator Reef.

2. Photograph showing SCUBA divers collecting a core of Holocene reef framework at Sombrero Reef using the U.S. Geological Survey wireline hydraulic drilling system

\section{Tables}

1. Information on cores collected from Sombrero, Tennessee, and Alligator Reefs in the Middle Florida Keys...... 


\section{Appendix Figures}

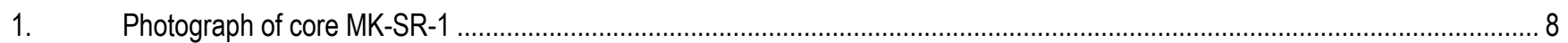

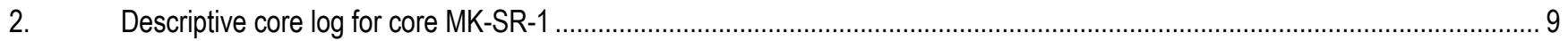

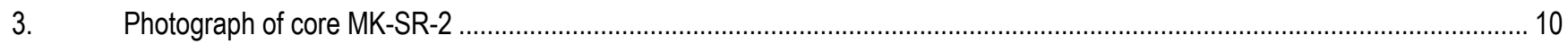

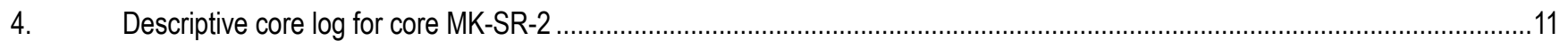

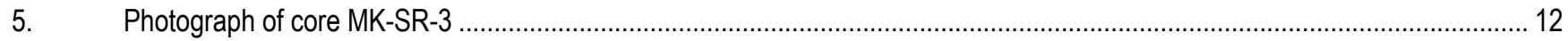

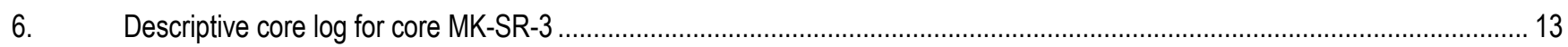

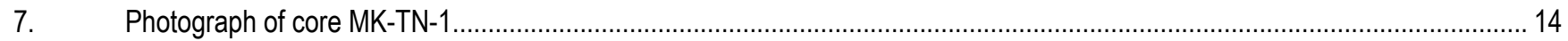

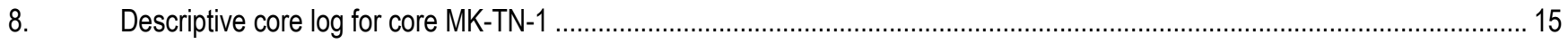

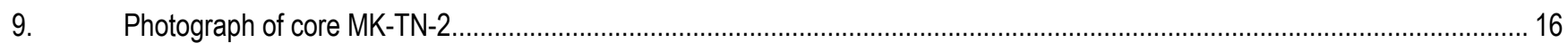

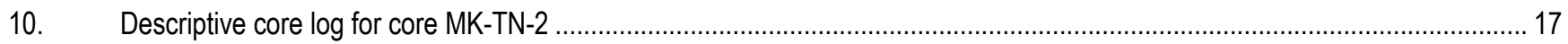

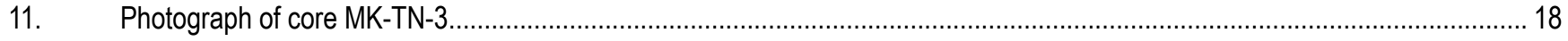

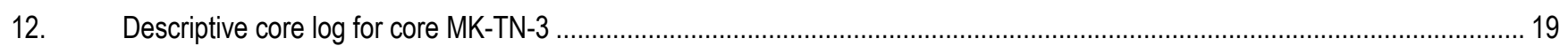

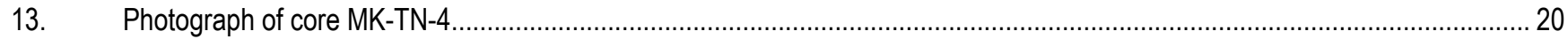

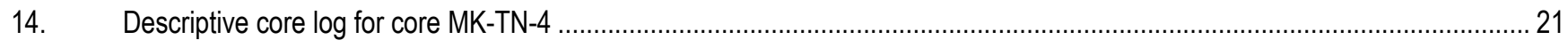

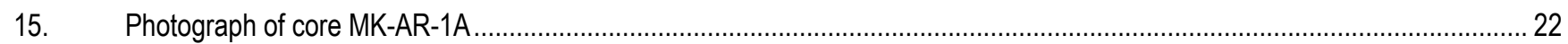

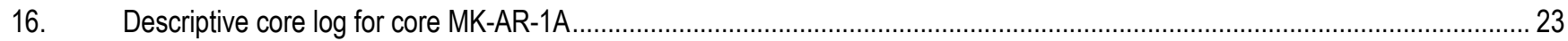

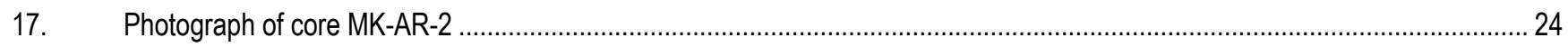

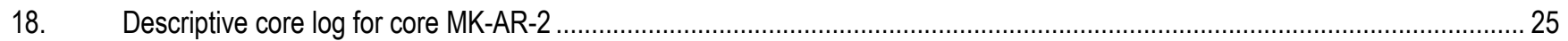

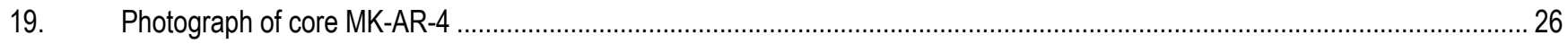

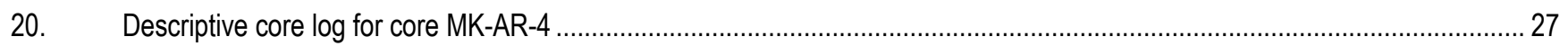




\section{Conversion Factors}

U.S. customary units to International System of Units

\begin{tabular}{ccc}
\hline Multiply & By & To obtain \\
\hline & Length & \\
\hline inch (in.) & 2.54 & centimeter (cm) \\
inch (in.) & 25.4 & millimeter (mm) \\
foot (ft) & 0.3048 & meter (m) \\
mile (mi) & 1.609 & kilometer (km) \\
\hline International System of Units to U.S. customary units & & \\
\hline Multiply & By & To obtain \\
\hline & Length & foot (ft) \\
\hline meter (m) & 3.281 & yard (yd) \\
\hline
\end{tabular}

\section{Datum}

Vertical coordinate information is referenced to the North American Vertical Datum of 1988 (NAVD 88).

\section{Abbreviations}

$\begin{array}{ll}\text { bMSL } & \text { below mean sea level } \\ \text { CPCe } & \text { Coral Point Count with Excel extensions } \\ \text { FKRT } & \text { Florida Keys reef tract } \\ \text { SE } & \text { standard error } \\ \text { USGS } & \text { U.S. Geological Survey } \\ \text { USGS-SP } & \text { St. Petersburg Coastal and Marine Science Center }\end{array}$




\title{
The Structure and Composition of Holocene Coral Reefs in the Middle Florida Keys
}

\author{
By Lauren T. Toth, Anastasios Stathakopoulos, and Ilsa B. Kuffner
}

\section{Introduction}

The Florida Keys reef tract (FKRT) is the largest coral-reef ecosystem in the continental United States. The modern FKRT extends for 362 kilometers along the coast of South Florida from Dry Tortugas National Park in the southwest, through the Florida Keys National Marine Sanctuary (FKNMS), to Fowey Rocks reef in Biscayne National Park in the northeast (fig. 1A, inset; Lidz and others, 2007). Most reefs along the FKRT are sheltered by the exposed islands of the Florida Keys; however, large channels are located between the islands of the Middle Keys (fig. 1A; Ginsburg and Shinn, 1994; Klein and Orlando, 1994; Precht and Miller, 2007). These openings allow for tidal transport of water from Florida Bay onto reefs in the area. The characteristics of the water masses coming from Florida Bay, which can experience broad swings in temperature, salinity, nutrients, and turbidity over short periods of time, are generally unfavorable or "inimical" to coral growth and reef development (Ginsburg and Shinn, 1994; Precht and Miller, 2007).

Although reef habitats are ubiquitous throughout most of the Upper and Lower Keys, relatively few modern reefs exist in the Middle Keys most likely because of the impacts of inimical waters from Florida Bay (Ginsburg and Shinn, 1994; Precht and Miller, 2007). The reefs that are present in the Middle Keys generally are poorly developed compared with reefs elsewhere in the region (Ginsburg and Shinn, 1994). For example, Acropora palmata has been the dominant coral on shallow-water reefs in the Caribbean over the last 1.5 million years until populations of the coral declined throughout the region in recent decades (Precht and Miller, 2007; Kuffner and Toth, 2016). Although A. palmata was historically abundant in the Florida Keys, it was conspicuously absent from reefs in the Middle Keys. Instead, contemporary reefs in the Middle Keys have been dominated by occasional massive (that is, boulder or head) corals and, more often, small, non-reef-building corals (Ginsburg and Shinn, 1994).

Holocene reef cores have been collected from many locations along the FKRT (Reich and others, 2012); however, despite the potential importance of the history of reefs in the Middle Florida Keys to our understanding of the environmental controls on reef development throughout the FKRT, there are currently no published records of the Holocene history of reefs in the region. The objectives of the present study were to (1) provide general descriptions of unpublished core records from Alligator Reef (fig. 1A; Robbin, 1981) and (2) collect and describe new Holocene reef cores from two additional locations in the Middle Keys: Sombrero (fig. 1B) and Tennessee Reefs (fig. 1C).

\section{Methods}

\section{Collection of Holocene Reef Cores}

Cores of Holocene reef framework were extracted from Sombrero and Tennessee Reefs (fig. 1A) in the summer of 2015 using the U.S. Geological Survey (USGS) rotary hydraulic coring system (fig. 2). SCUBA divers suspended the hydraulic submersible drill rig above the reef using a tripod. The system uses a standard NQ-2 double-barrel wireline system, which allows intervals of the reef framework to be sampled by recovering the 5.1-centimeter- (cm; 2-inch [in.]) diameter inner barrel containing the core 


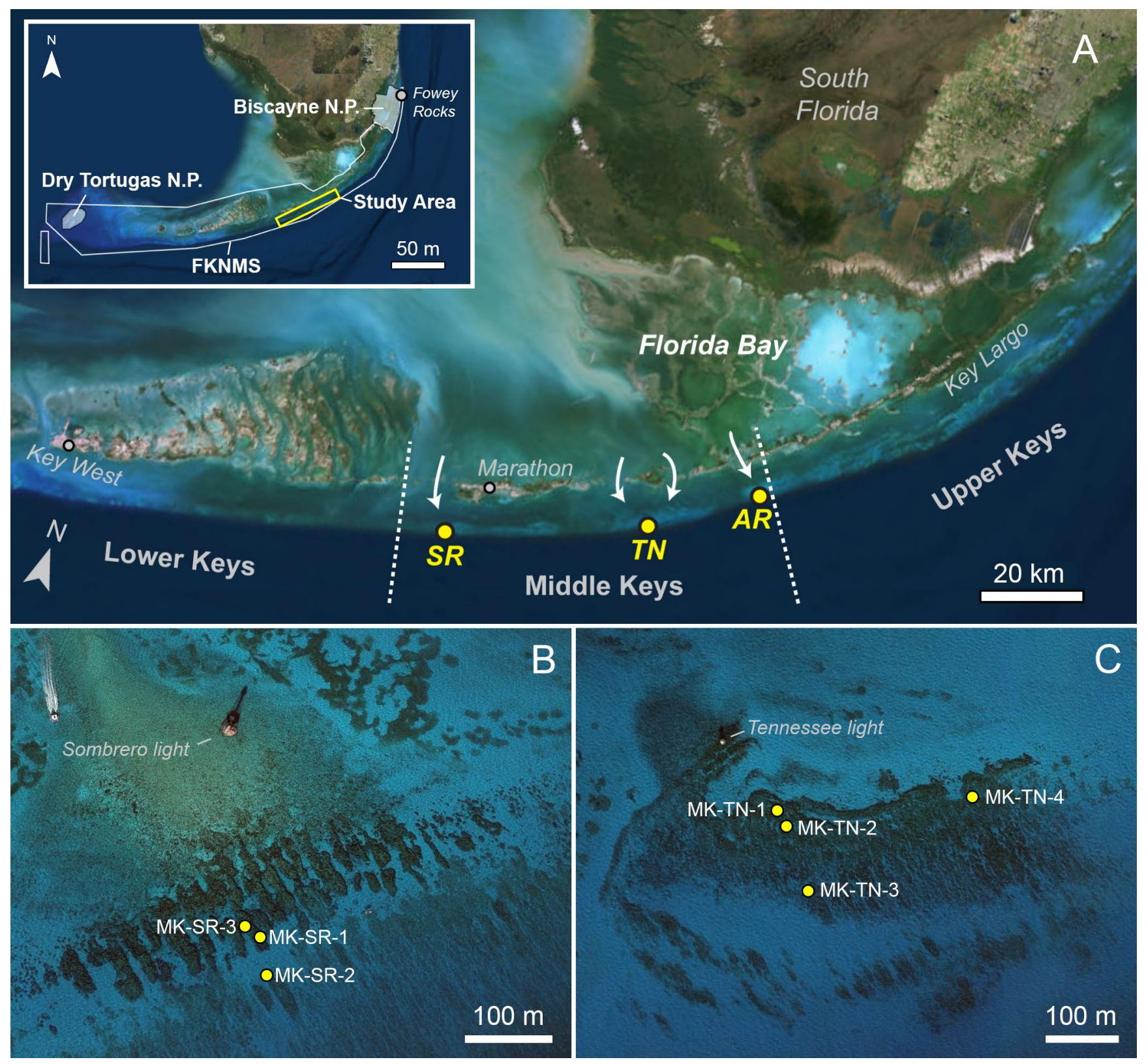

Figure 1. (A) Map of the Florida Keys showing the location of the coring sites in the Middle Keys sector: Sombrero Reef (SR), Tennessee Reef (TN), and Alligator Reef (AR). Arrows indicate the location of tidal passes between Florida Bay and the reef tract. Geographic divisions between sectors are from Klein and Orlando (1994). The inset shows the location of the study area within the Florida Keys reef tract (FKRT). Maps of coring locations at (B) Sombrero and (C) Tennessee Reefs. Imagery in the upper panel was obtained from the base map library in ESRI@ ArcGIS 10.2.2 for Desktop. The two lower maps were created in Google Earth v. 7.1.5.1557. Imagery date: January 16, 2014. Accessed: December 8, 2015.

sample, while the outer barrel remains in the reef. Water is circulated continuously through the core barrels to clear sediment and facilitate coring. Reef cores were collected by adding consecutive, 1.5-meter(m; 5-foot) long outer barrels, until the Pleistocene bedrock was reached. Intervals of reef framework were not always recovered in 1.5 -m sections, however, but were instead extracted when the drilling process slowed. Additional information on coring methods can be found in Macintyre (1975) and Reich and others (2009). 


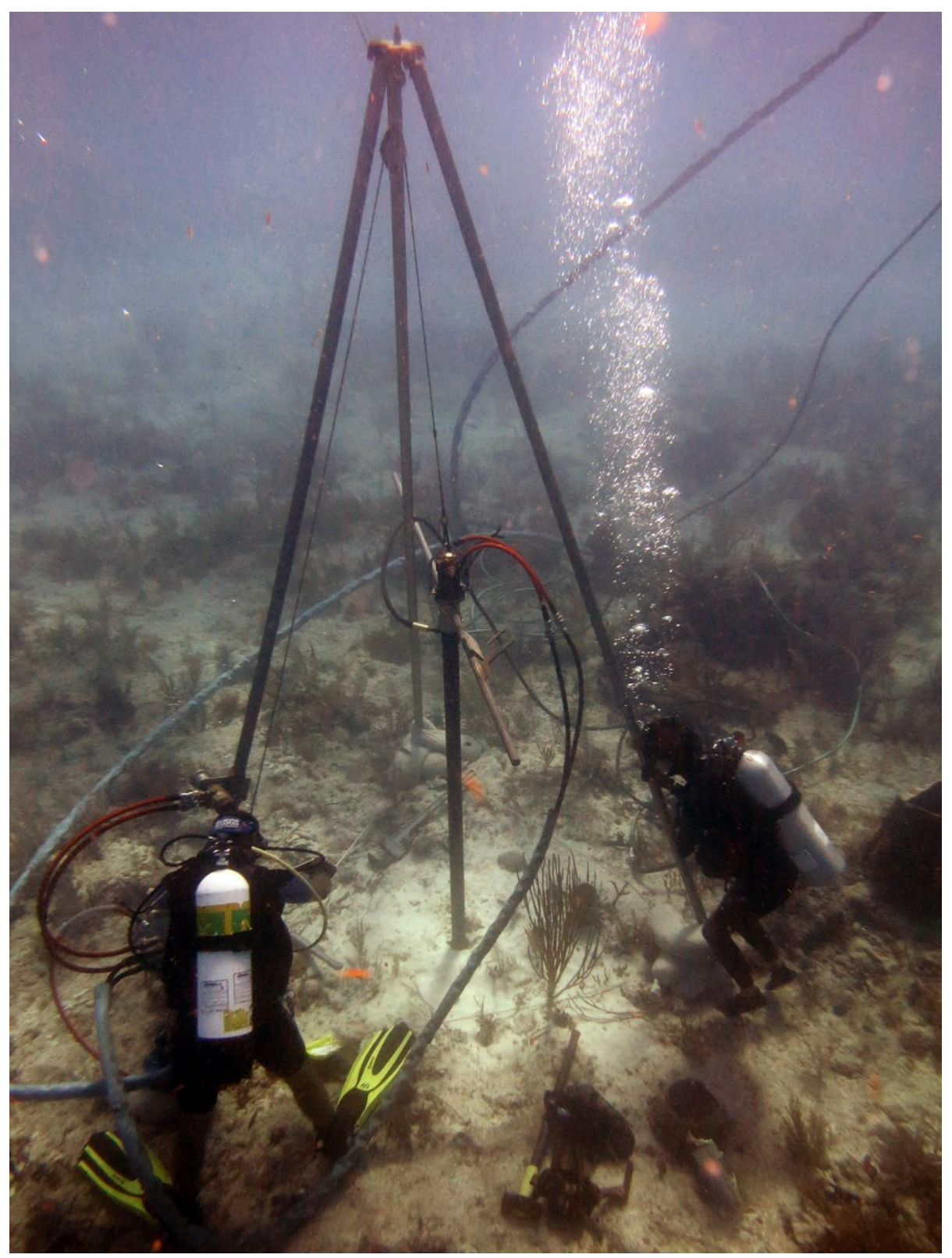

Figure 2. SCUBA divers collecting a core of Holocene reef framework at Sombrero Reef using the U.S. Geological Survey wireline hydraulic drilling system.

Divers carefully noted drilling character (that is, the drilling speed and resistance) and core penetration throughout the coring process to aid in the construction of core logs. Water depth at each coring site was recorded using dive computers. Using the time and date of the measurements, the depth was adjusted to meters $(\mathrm{m})$ below mean sea level (bMSL) using data from the National Oceanic and Atmo-

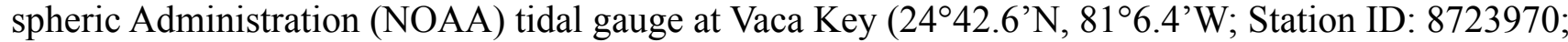
https://tidesandcurrents.noaa.gov/tide_predictions.html). At Sombrero Reef, a transect of three cores was collected along a centrally located reef spur at 3.6 to $7.5 \mathrm{~m}$ depth bMSL (table 1; fig. 1B). A transect of three cores was also collected along the western end of Tennessee Reef at 5.2 to 9.2 m bMSL (table 1; fig. 1C). A fourth core was collected from the eastern side of Tennessee Reef at $6.2 \mathrm{~m}$ bMSL. 
Table 1. Information on cores collected from Sombrero, Tennessee, and Alligator Reefs in the Middle Florida Keys.

[Site locations for Sombrero Reef and Tennessee Reef are shown in figure 1. Site locations for Alligator Reef are unknown. Latitude and longitude are decimal degrees referenced to the North American Datum of 1983. *, approximate values]

\begin{tabular}{clllccc}
\hline Site Name & Core ID & Collection date(s) & Latitude & Longitude & $\begin{array}{c}\text { Core length, in } \\
\text { meters }\end{array}$ & $\begin{array}{c}\text { Water depth, in } \\
\text { meters }\end{array}$ \\
\hline Sombrero Reef & MK-SR-1 & June 12-15, 2015 & 24.6257 & -81.1105 & 5.1 & 5.6 \\
& MK-SR-2 & June 16-18, 2015 & 24.6254 & -81.1104 & 8.1 & 7.5 \\
& MK-SR-3 & June 20-21, 2015 & 24.6258 & -81.1106 & 4.9 & 3.6 \\
Tennessee Reef & MK-TN-1 & Sept. 3-4, 2015 & 24.7452 & -80.7816 & 6.4 & 5.2 \\
& MK-TN-2 & Sept. 5, 2015 & 24.7450 & -80.7816 & 4.6 & 6.1 \\
& MK-TN-3 & Sept. 6-8, 2015 & 24.7442 & -80.7812 & 4.0 & 9.2 \\
Alligator Reef & MK-TN-4 & Sept. 9, 2015 & 24.7454 & -80.7789 & 4.6 & 6.2 \\
& MK-AR-1A & July 14, 1981 & $24.8504^{*}$ & $-80.6164^{*}$ & 3.0 & $5.0^{*}$ \\
& MK-AR-2 & July 14, 1981 & $24.8504^{*}$ & $-80.6164^{*}$ & 2.3 & $5.0^{*}$ \\
& MK-AR-4 & July 15, 1981 & $24.8504^{*}$ & $-80.6164^{*}$ & 3.2 & $3.8^{*}$ \\
\hline
\end{tabular}

The cores from Alligator Reef (fig. 1A) were collected in July 1980 (Robbin, 1981) and are archived at the USGS St. Petersburg Coastal and Marine Science Center (USGS-SP; http://olga.er.usgs. gov/coreviewer/; Reich and others, 2012). These cores were collected using a hydraulic coring system similar to that used to collect the cores from Sombrero and Tennessee Reefs (Robbin, 1981); however, the diameter of the core barrel was smaller: 3.9 centimeters $(1.5 \mathrm{in}$.) rather than $5.1 \mathrm{~cm}(2 \mathrm{in}$.). Exact coring locations on Alligator Reef are unknown, and it is not known if any detailed drilling notes for these cores exist. Water depths for each core were taken from notes on the core boxes or from unpublished field notebooks and should be considered approximate as they cannot be corrected to mean sea level.

\section{Analysis of Core Composition}

In order to capture high-resolution images of the core records, three photographs of each core were taken using a Canon EOS Rebel digital camera. Photographic core logs were generated by creating high-resolution photo-mosaics of the three core photographs using the Photomerge tool in Adobe ${ }^{\circledR}$ Photoshop ${ }^{\circledR}$. Using the cores for reference, all recovered reef material visible in the photographic core logs was identified. Coral skeletons were generally identified to the genus level; however, acroporid corals were further classified as either Acropora palmata or Acropora cervicornis, and Porites spp. were identified as either Porites astreoides or "branching Porites spp." on the basis of structural morphology of the coral skeletons. Carbonate reef rocks that were formed as a result of secondary binding of reef sediment were categorized as "packstone/grainstone" after Dunham (1962). Simplified core logs were generated for each core using RockWare $^{\odot} \operatorname{LogPlot}^{\mathrm{TM}} 7$ software.

The composition of each core was quantified by tracing the projected surface area of each core component on the digital core photographs using the Area Analysis Tool in the program Coral Point Count with Excel extensions (CPCe; Kohler and Gill, 2006). The data collected in CPCe were used to determine percentage recovery and percentage composition of coral taxa within each recovered interval of the cores. First, the theoretical projected surface area was calculated by multiplying the diameter of the core as measured in CPCe by the actual penetration depth of that core interval. Percentage recovery was then determined by dividing the total measured area of each interval by the theoretical projected surface area of that interval. Similarly, the absolute percentage composition of coral taxa was calculated 
by dividing the total surface area of each taxa in each interval by the theoretical surface area of that interval (see Toth and others, 2015). These data were included in the final core logs for each core.

\section{Results and Discussion}

\section{General Descriptions of the Cores}

Recovery of reef carbonates (corals, grainstones/packstones, and unconsolidated sediments) in the cores averaged 35.5 percent ( \pm 4.4 standard error $[\mathrm{SE}]$ ); however, recovery was highly variable among the cores and among intervals within cores (range of recovery: 0-92.5 percent; see core logs in appendix 1). A laminated, calcitic ("soilstone") crust, which is characteristic of the subaerially exposed upper surface of Pleistocene limestones in the Florida Keys (Multer and Hoffmeister 1968), was present in five of the ten cores (red line on the core logs in appendix figures 3, 9, 11, 15, and 19). The soilstone crust was present at $1.5 \mathrm{~m}$ depth below the reef surface in one core from Alligator Reef (MK-AR-2; appendix figure 19) or $6.5 \mathrm{~m}$ bMSL; however, the boundary between the Holocene and Pleistocene facies occurred deeper-3.7-4.9 $\mathrm{m}$ depth - in the other four cores, which corresponds to 9.5-10.2 $\mathrm{m}$ bMSL. Thus, although recent reef development in the Middle Keys has been poor compared with other reefs on the FKRT (Ginsburg and Shinn 1994), Sombrero, Tennessee, and Alligator Reefs all accumulated several meters of reef framework during the Holocene.

\section{Composition of the Cores}

Together, three coral taxa-Acropora palmata, Orbicella spp., and Diploria spp.- - accounted for about 71.4 percent of all recovered carbonate from the Middle Keys cores (appendix 1). Orbicella spp. and A. palmata have been the dominant framework-building corals in the Caribbean throughout most of the Quaternary period ( 1.5 million years ago to present; Precht and Miller 2007; Toth and others, 2015; Kuffner and Toth, 2016). Acropora palmata and Orbicella spp. were also the dominant corals on these Holocene reefs in the Middle Keys, accounting for 30.0 percent and 27.1 percent of the recovered material, respectively. Whereas $A$. palmata is currently absent from most reefs in the Middle Keys (Ginsburg and Shinn 1994), its high abundance in the cores suggests that it was a dominant coral on these reefs at some point during the Holocene.

Diploria spp., which made up 14.2 percent of the record, were common, but not dominant in the cores. The remaining coral taxa, which included $P$. astreoides, various branching Porites spp., Dichocoenia stokesii, and Acropora cervicornis, only accounted for 6.3 percent of the core composition. The remaining approximately 22.5 percent of the cores consisted of other carbonate material, primarily grainstones and packstones.

\section{Acknowledgments}

The cores from Sombrero and Tennessee Reefs were collected by L.T.T and A.S. under permit number FKNMS-2015-058. We thank B.J. Reynolds, Hunter Wilcox, Marc Blouin, and Jen Morrison of the USGS for their assistance in collecting these cores. The cores from Alligator Reef were collected by Daniel M. Robbin and J. Harold Hudson of the USGS. This study was funded by a Mendenhall Research Fellowship awarded to L.T.T. by the U.S. Geological Survey (USGS) Coastal Marine Geology Program and the Natural Hazards Mission Area. 


\section{References Cited}

Dunham, R.J., 1962, Classification of carbonate rocks according to depositional texture, in Hamm, W.E., ed., Classification of carbonate rocks, A symposium: American Association of Petroleum Geologists, p. 108-121, accessed July 31, 2014, at http://archives.datapages.com/data/specpubs/carbona2/data/a038/a038/0001/0100/0108.htm.

Ginsburg, R.N., and Shinn, E.A., 1994, Preferential distribution of reefs in the Florida Reef Tract-The past is the key to the present, in Ginsburg, R.N., comp., Proceedings of the Colloquium on global aspects of coral reefs - Health, hazards, and history: University of Miami, Florida, Rosenstiel School of Marine and Atmospheric Science, p. 21-26.

Klein, C.J., III, and Orlando, S.P., Jr., 1994, A spatial framework for water quality management in the Florida Keys National Marine Sanctuary: Bulletin of Marine Science, v. 54, p. 1036-1044, accessed July 8, 2015, at http:/www.ingentaconnect.com/content/umrsmas/bullmar/1994/00000054/00000003/ art00033?crawler=true.

Kohler, K.E., and Gill, S.M., 2006, Coral Point Count with Excel extensions (CPCe)—A Visual Basic program for the determination of coral and substrate coverage using random point count methodology: Computers and Geosciences, v. 32, p. 1259-1269, accessed April 25, 2016, at http://cnso.nova.edu/cpce/.

Kuffner, I.B., and Toth, L.T., 2016, A geological perspective on the degradation and conservation of western Atlantic coral reefs: Conservation Biology, accessed May 12, 2016, at http://onlinelibrary.wiley.com/doi/10.1111/cobi.12725/abstract.

Lidz, B.H., Reich, C.D., and Shinn, E.A., 2007, Systematic mapping of bedrock and habitats along the Florida reef tract - Central Key Largo to Halfmoon shoal: U.S. Geological Survey Professional Paper 1751, accessed April 25, 2016, at http://pubs.usgs.gov/pp/2007/1751/.

Macintyre, I.G., 1975, A diver-operated hydraulic drill for coring submerged substrates: Atoll Research Bulletin, v. 185, p. 21-26.

Multer, H.G., and Hoffmeister, J.E., 1968, Subaerial laminated crusts of the Florida Keys: Geological Society of America Bulletin, v. 79, p. 183-192, accessed April 14, 2016, at http://gsabulletin.gsapubs.org/content/79/2/183.short\#cited-by.

Precht, W.F., and Miller, S.L., 2007, Ecological shifts along the Florida reef Tract-The past as a key to the future, in Aronson, R.B., ed., Geological approaches to coral reef ecology: New York, Springer Science+Business Media, LLC, p. 237-312.

Reich, C.D., Hickey, T.D., Delong, K.L., Poore, R.Z., and Brock, J.C., 2009, Holocene core logs and site statistics for modern patch-reef cores-Biscayne National Park: U.S. Geological Survey Open-File Report 2009-1246, accessed September 10, 2013, at http://pubs.er.usgs.gov/publication/ofr20091246.

Reich, C.D., Streuebert, M., Dwyer, B., Godbout, M., Muslic, A., and Umberger, D., 2012, St. Petersburg Coastal and Marine Science Center's core archive portal: U.S. Geological Survey Data Series 626, accessed March 24, 2015, at http://pubs.usgs.gov/ds/626/.

Robbin, D.M., 1981, Subaerial $\mathrm{CaCO}_{3}$ crust-A tool for timing reef initiation and defining sea level changes, in Fourth International Coral Reef Symposium, Manila, p. 575-579, accessed July 17, 2014, at http://www.reefbase.org/resource_center/publication/pub_4779.aspx.

Toth, L.T., Kuffner, I.B., Cheng, H., and Edwards, R.L., 2015, A new record of the late Pleistocene coral Pocillopora palmata from the Dry Tortugas, Florida reef tract, U.S.A.: Palaios, v. 30, p. 1-9, accessed April 25, 2016, at http://palaios.geoscienceworld.org/content/30/12/827.full. 


\section{Appendix 1. Photographs and Descriptive Logs of Holocene Reef Cores from the Middle Florida Keys}

\section{EXPLANATION}

Core log symbols

₹ Acropora palmata
Acropora cervicornis
\& Massive coral
\& Branching Porites spp.
— Grainstone/packstone
— Soilstone crust

Core composition

$\square$ Acropora palmata

$\square$ Orbicella spp.

$\square$ Diploria spp.

$\square$ Other corals

Grainstone/packstone 


\section{Sombrero Reef: MK-SR-1}

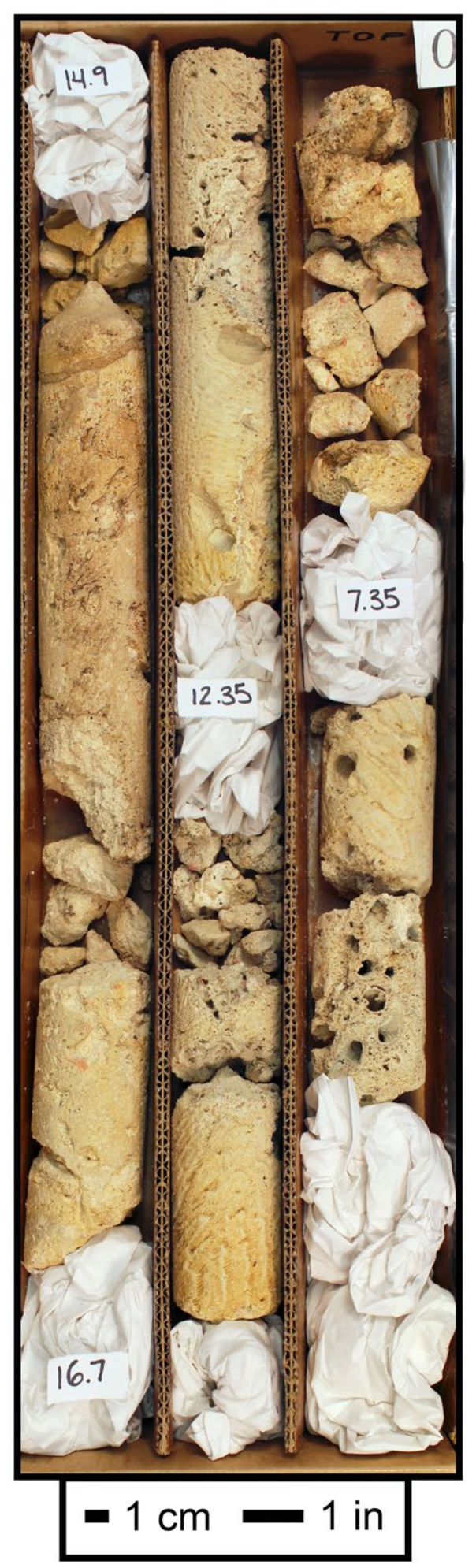

Appendix Figure 1. Photograph of core MK-SR-1. 


\section{CORE NAME:Sombrero Reef \#1 (MK-SR-1)}

Location: Sombrero Reef, Florida Keys National Marine Sanctuary

Drilled By: Toth, L.T.; Stathakopoulos, A.; Reynolds, B.J.; Blouin, M.; Morrison, J.M.

Date Cored: 6/11/2015

Logged By: Toth, L.T.

Water Depth: $18.3 \mathrm{ft}(5.6 \mathrm{~m})$

Latitude: $\quad 24.6257$

Longitude: $\quad-81.1105$

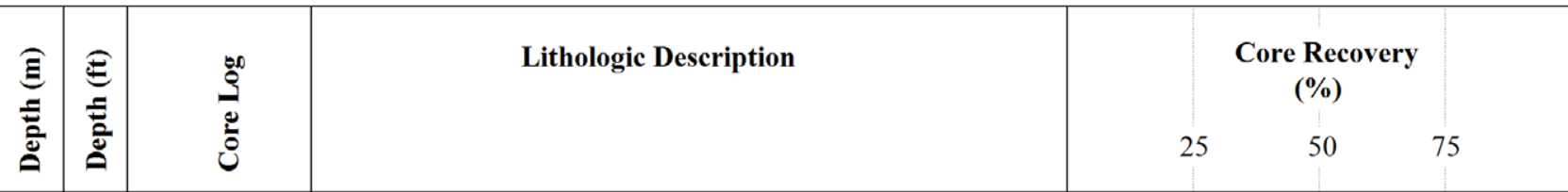

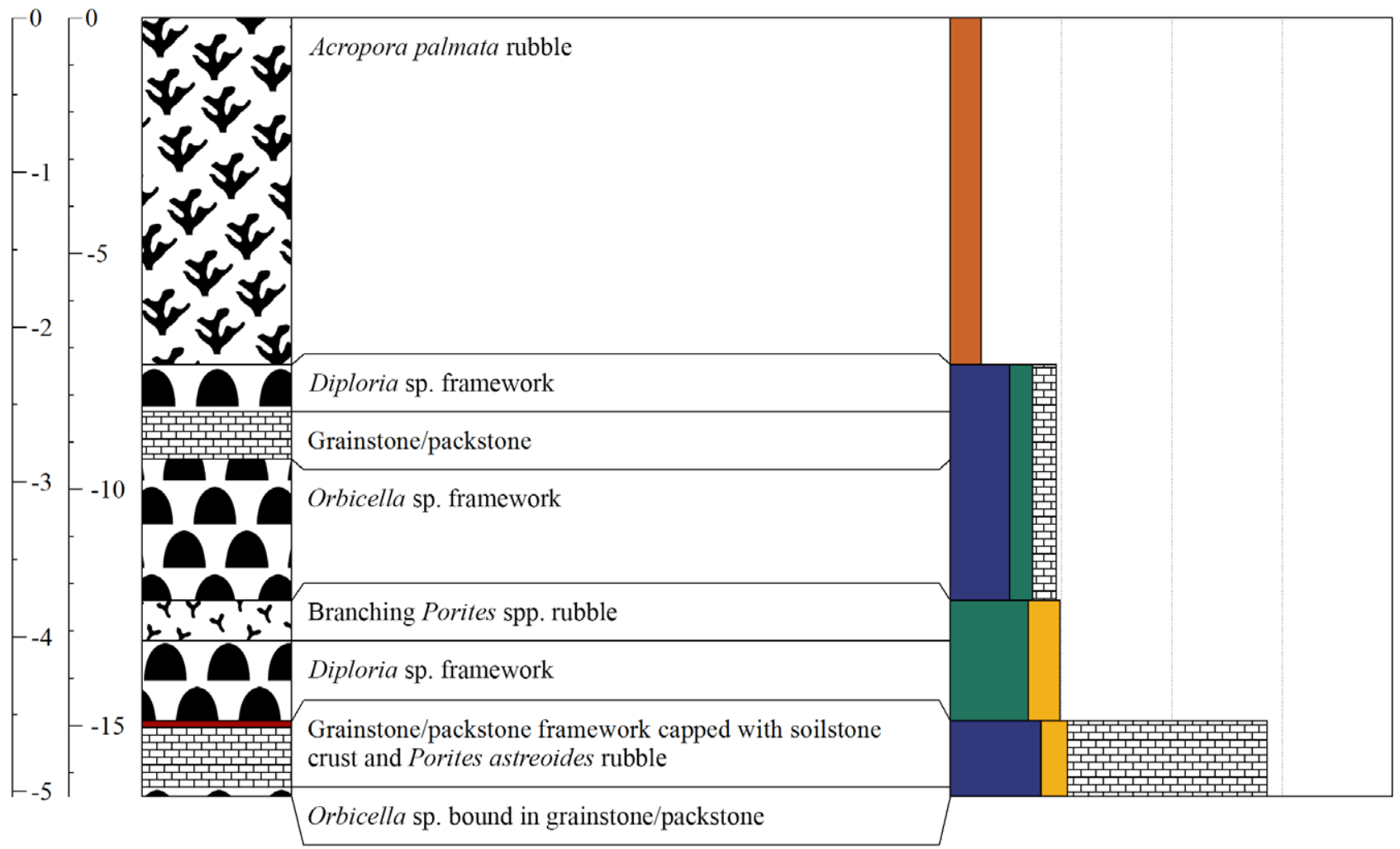

Appendix Figure 2. Descriptive core log for core MK-SR-1. 


\section{Sombrero Reef: MK-SR-2}

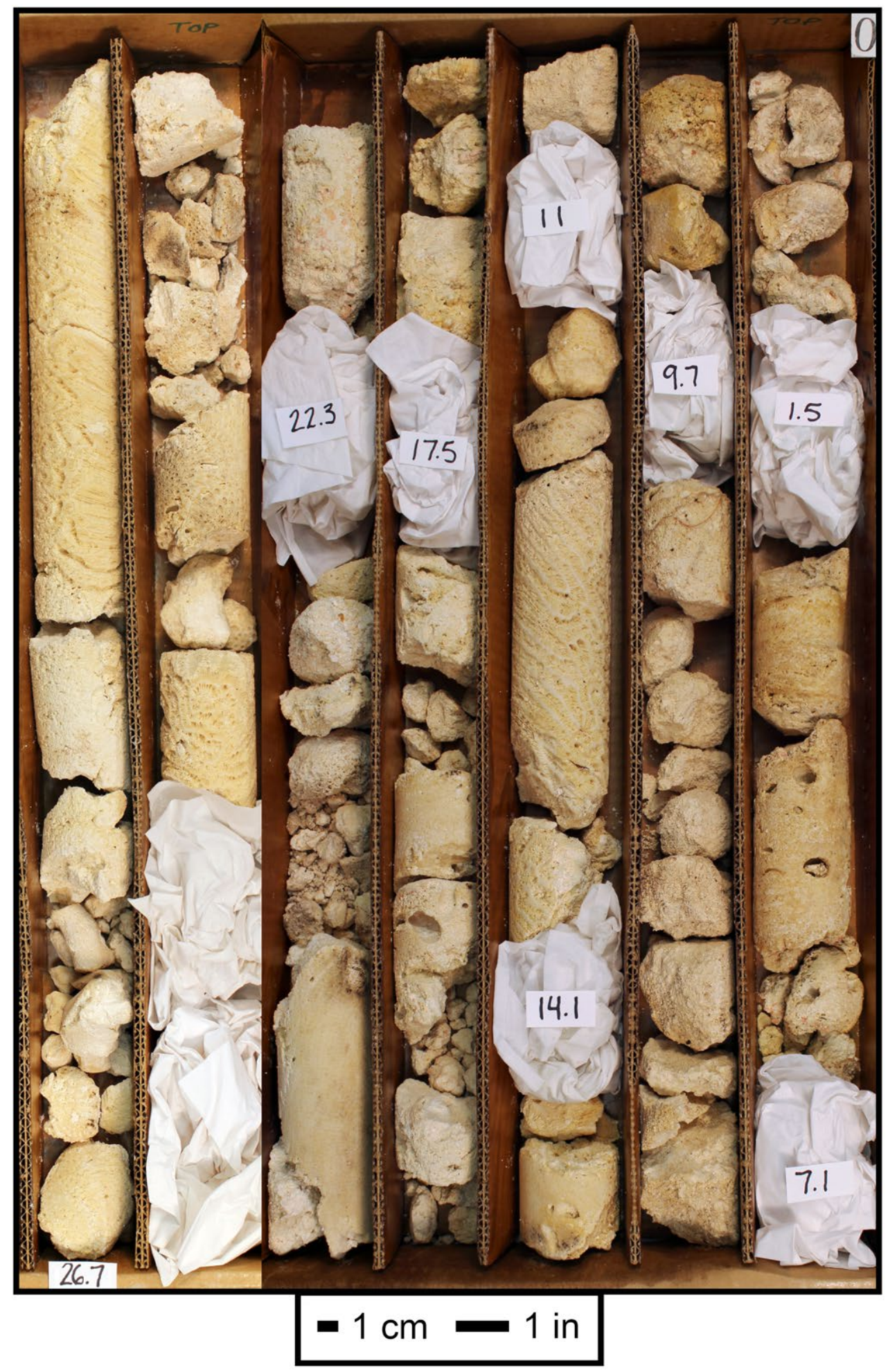

Appendix Figure 3. Photograph of core MK-SR-2. 


\section{CORE NAME: Sombrero Reef \#2 (MK-SR-2)}

Location: Sombrero Reef, Florida Keys National Marine Sanctuary

Drilled By: Toth, L.T.; Stathakopoulos, A.; Reynolds, B.J.; Morrison, J.M.; Blouin, M.

Logged By: Toth, L.T.

Date Cored: $6 / 18 / 2015$

Water Depth: $24.7 \mathrm{ft}(7.5 \mathrm{~m})$

Latitude: $\quad 24.6254$

Longitude: $\quad-81.1104$

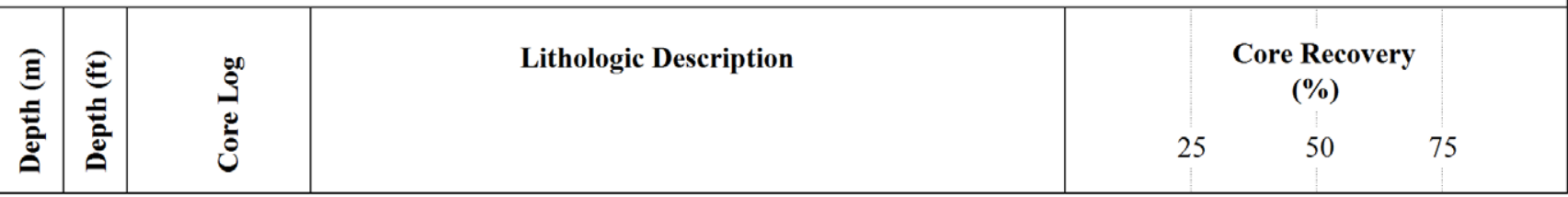

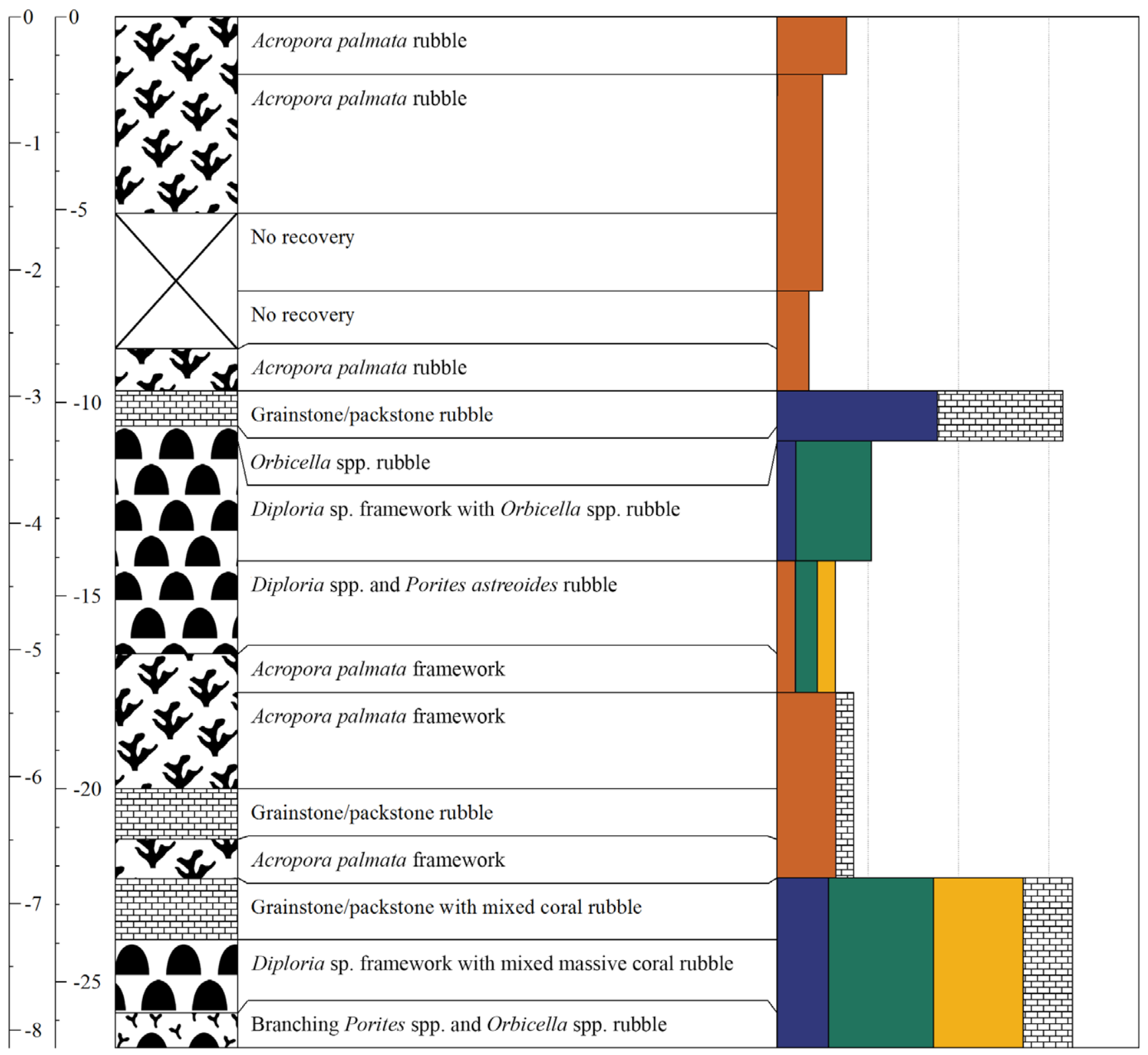

Appendix Figure 4. Descriptive core log for core MK-SR-2. 


\section{Sombrero Reef: MK-SR-3}

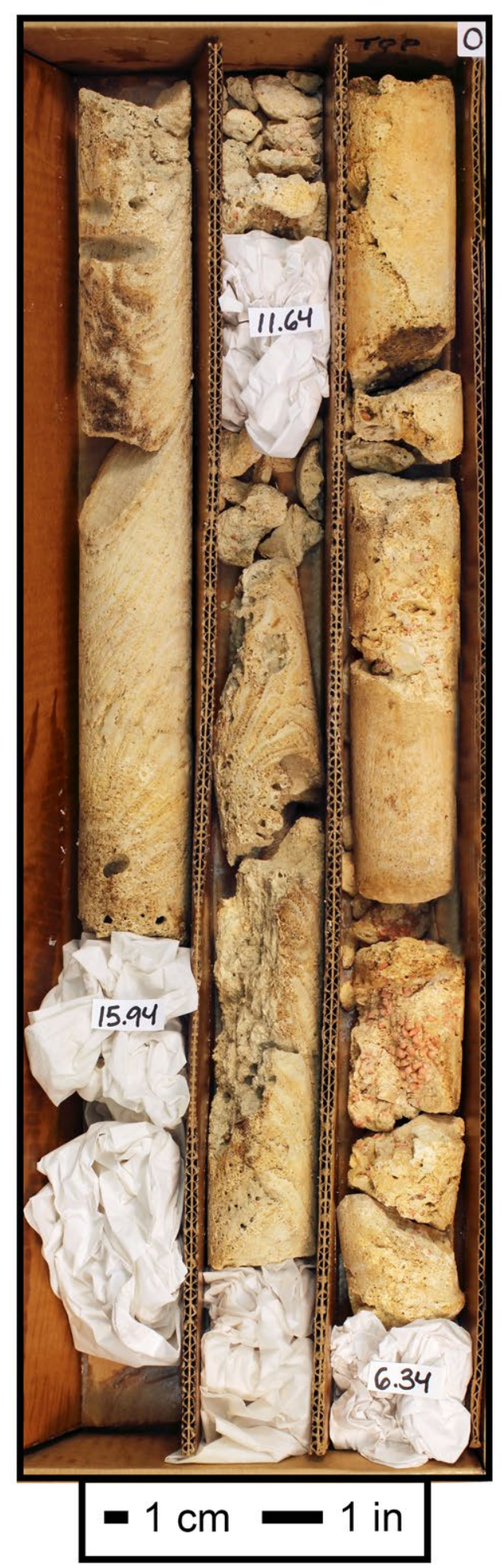

Appendix Figure 5. Photograph of core MK-SR-3. 


\section{CORE NAME:Sombrero Reef \#3 (MK-SR-3)}

Location: Sombrero Reef, Florida Keys National Marine Sanctuary

Drilled By: Toth, L.T.; Stathakopoulos, A.; Reynolds, B.J.; Morrison, J.M.; Blouin, M.

Logged By: Toth, L.T.

Date Cored: 6/21/2015

Water Depth: $11.7 \mathrm{ft}(3.6 \mathrm{~m})$

Latitude: $\quad 24.6258$

Longitude: $\quad-81.1106$

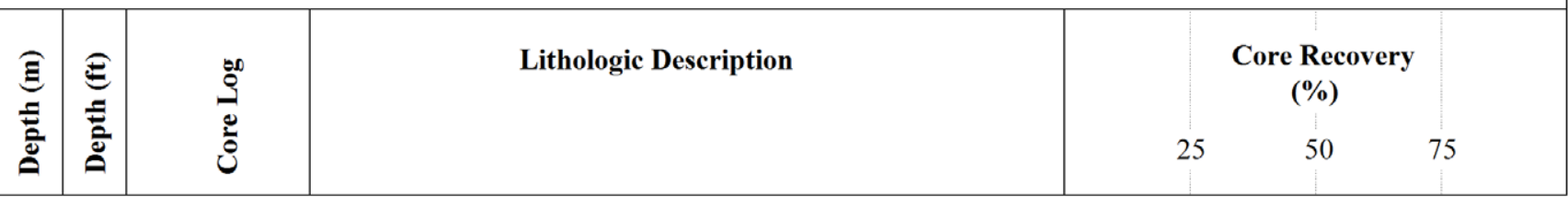

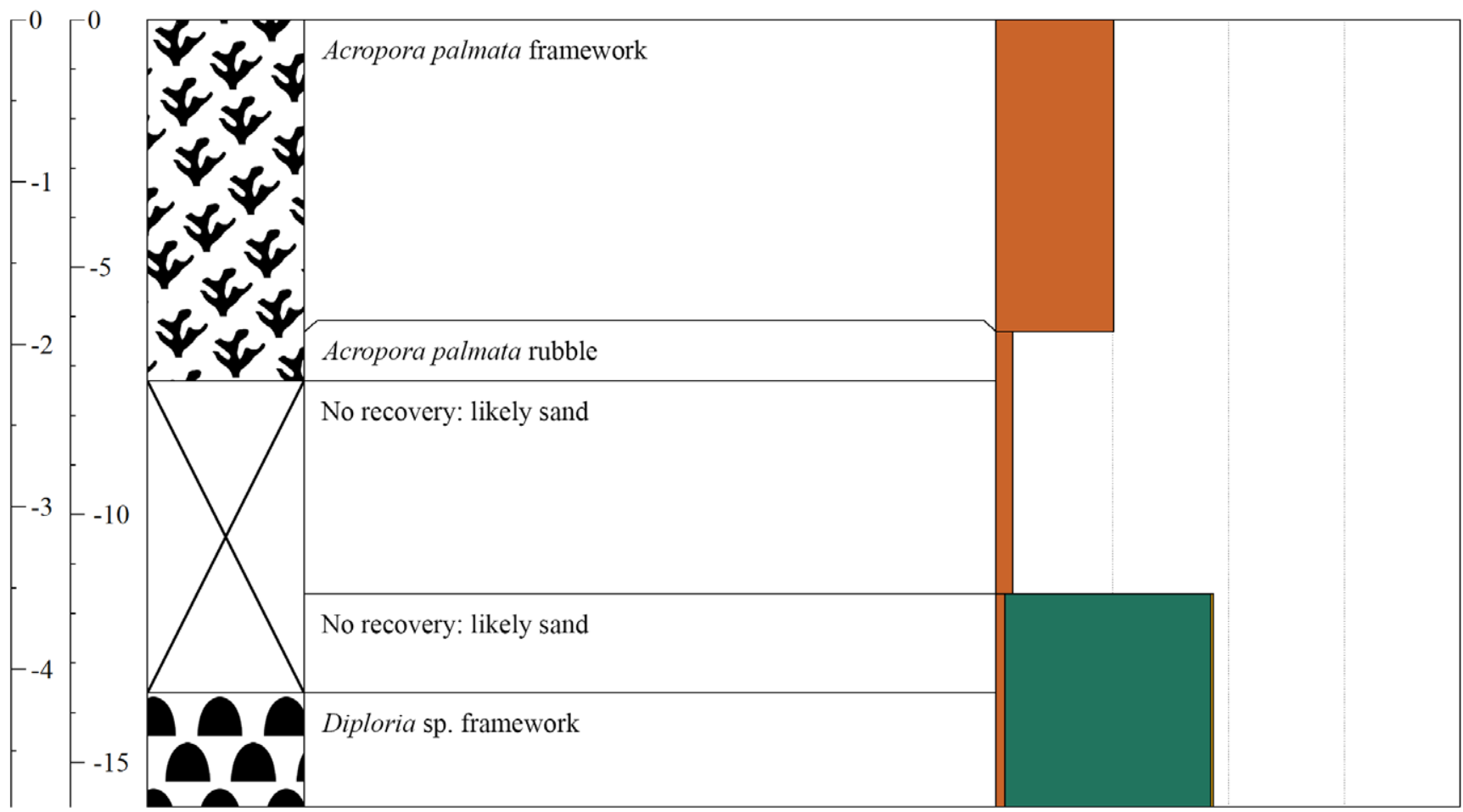

Appendix Figure 6. Descriptive core log for core MK-SR-3. 
Tennessee Reef: MK-TN-1

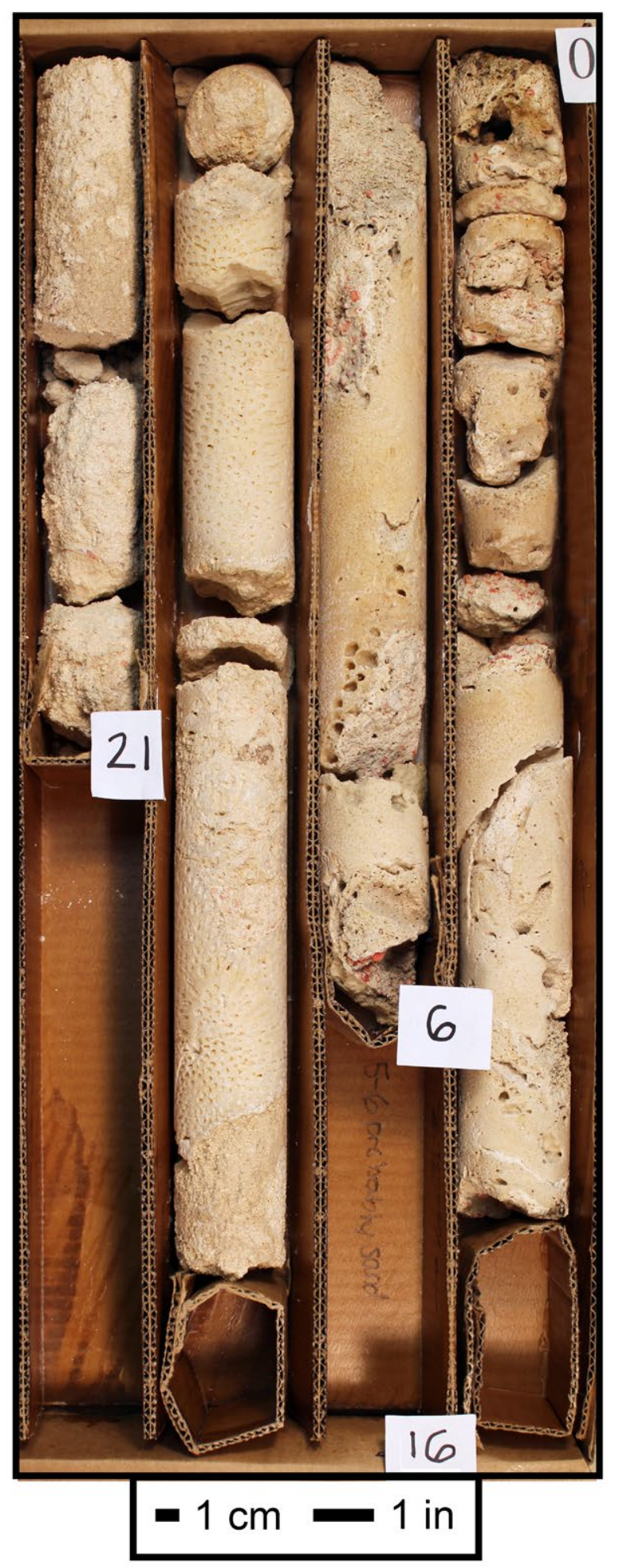

Appendix Figure 7. Photograph of core MK-TN-1. 


\section{CORE NAME:Tennessee Reef \#1 (MK-TN-1)}

Location: Tennessee Reef, Florida Keys National Marine Sanctuary

Drilled By: Toth, L.T.; Stathakopoulos, A.; Reynolds, B.J.; Wilcox, H.

Logged By: Toth, L.T.

Date Cored: $9 / 3 / 2015$

Water Depth: $16.9 \mathrm{ft}(5.2 \mathrm{~m})$

Latitude: 24.7452

Longitude: $\quad-80.7816$

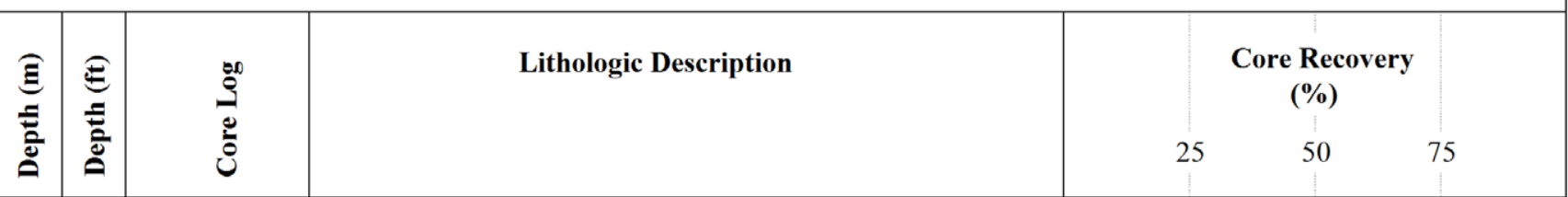

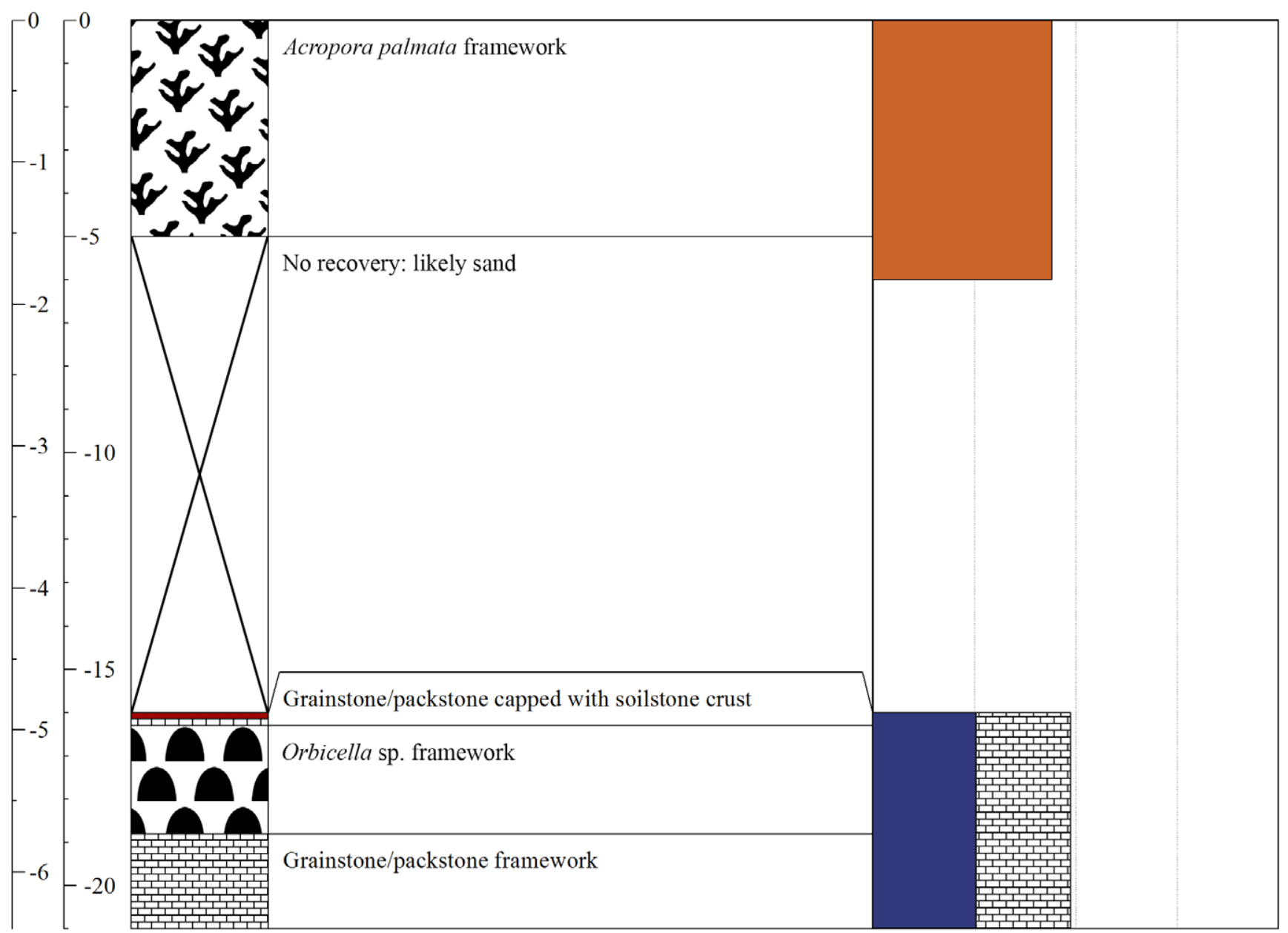

Appendix Figure 8. Descriptive core log for core MK-TN-1. 


\section{Tennessee Reef: MK-TN-2}

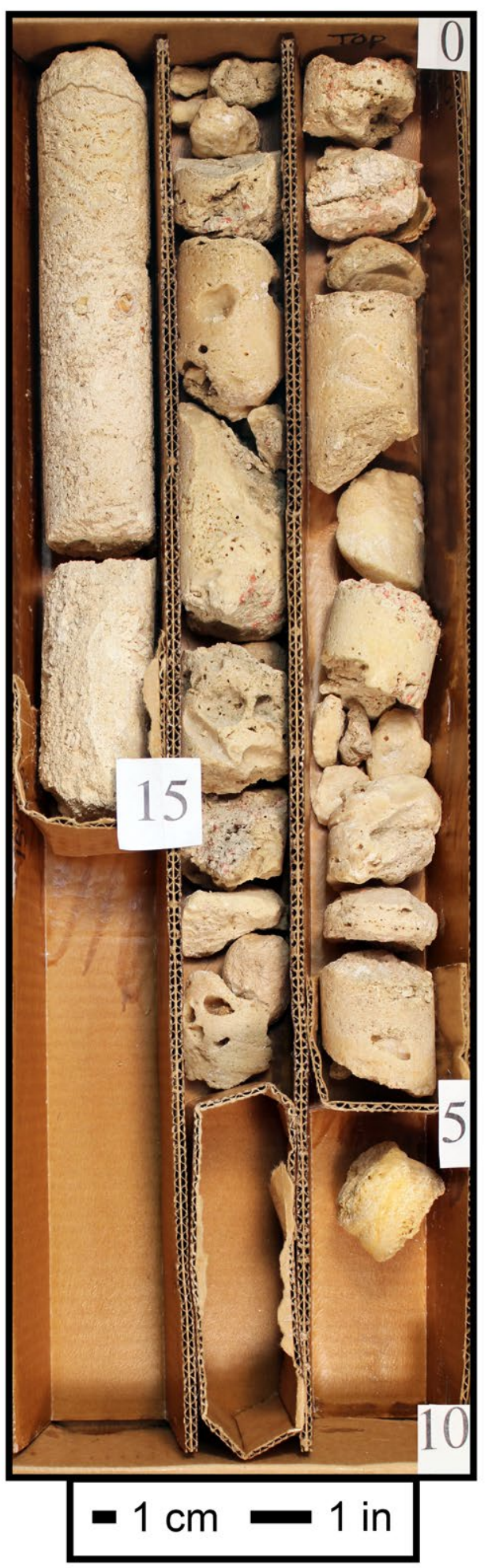

Appendix Figure 9. Photograph of core MK-TN-2 . 


\section{CORE NAME:Tennessee Reef \#2 (MK-TN-2)}

Location: Tennessee Reef, Florida Keys National Marine Sanctuary

Drilled By: Toth, L.T.; Stathakopoulos, A.; Reynolds, B.J.; Wilcox, H.

Logged By: Toth, L.T.

Date Cored: $9 / 5 / 2015$

Water Depth: $21.2 \mathrm{ft}(6.5 \mathrm{~m})$

Latitude: $\quad 24.7450$

Longitude: $\quad-80.7815$

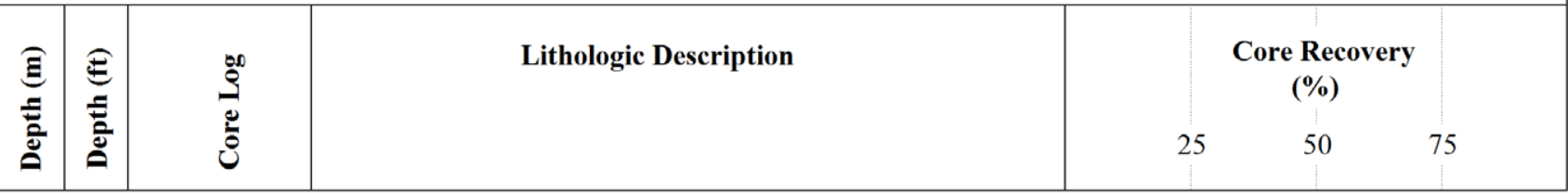

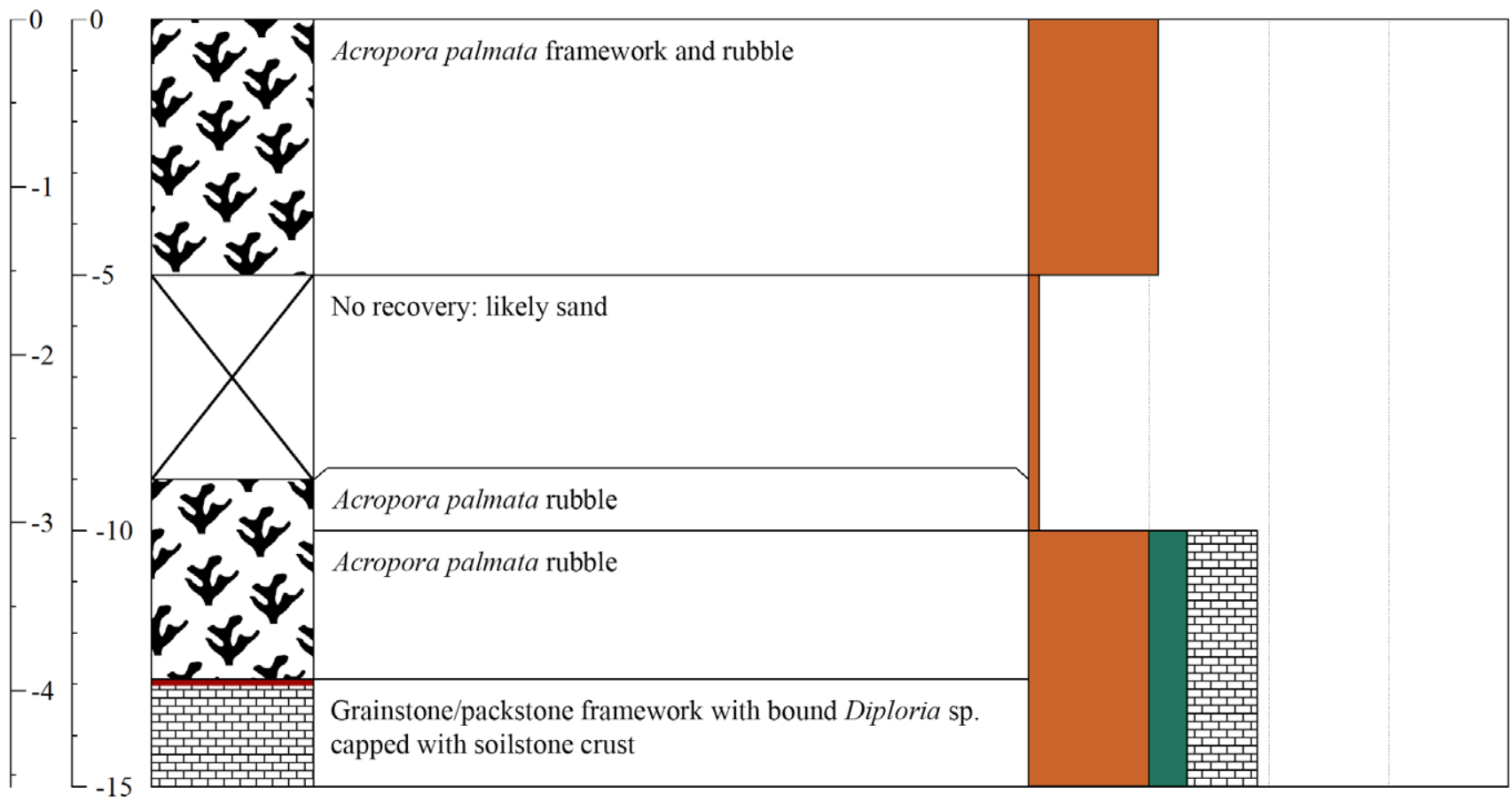

Appendix Figure 10. Descriptive core log for core MK-TN-2. 


\section{Tennessee Reef: MK-TN-3}

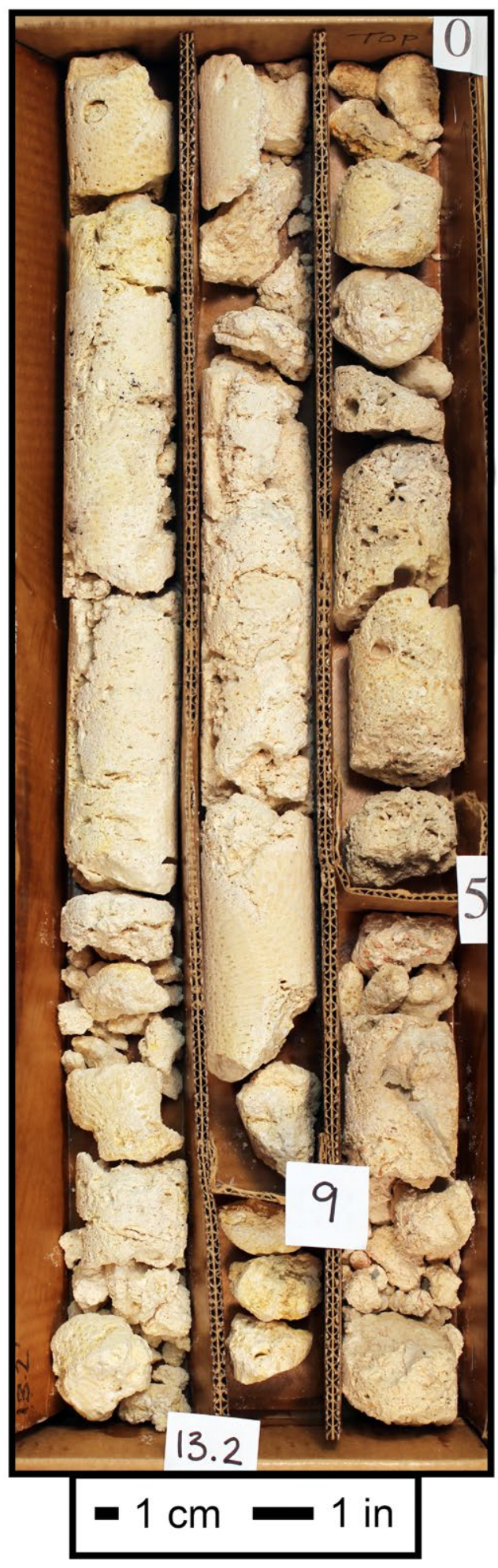

Appendix Figure 11. Photograph of core MK-TN-3. 


\section{CORE NAME:Tennessee Reef \#3 (MK-TN-3)}

Location: Tennessee Reef, Florida Keys National Marine Sanctuary

Date Cored: 9/6/2015

Drilled By: Toth, L.T.; Stathakopoulos, A.; Reynolds, B.J.; Wilcox, H.

Water Depth: $30.1 \mathrm{ft}(9.2 \mathrm{~m})$

Logged By: Toth, L.T.

Latitude: 24.7442

Longitude: $\quad-80.7812$

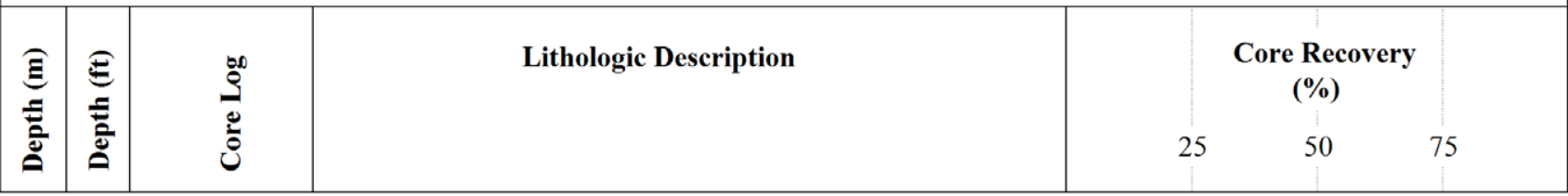

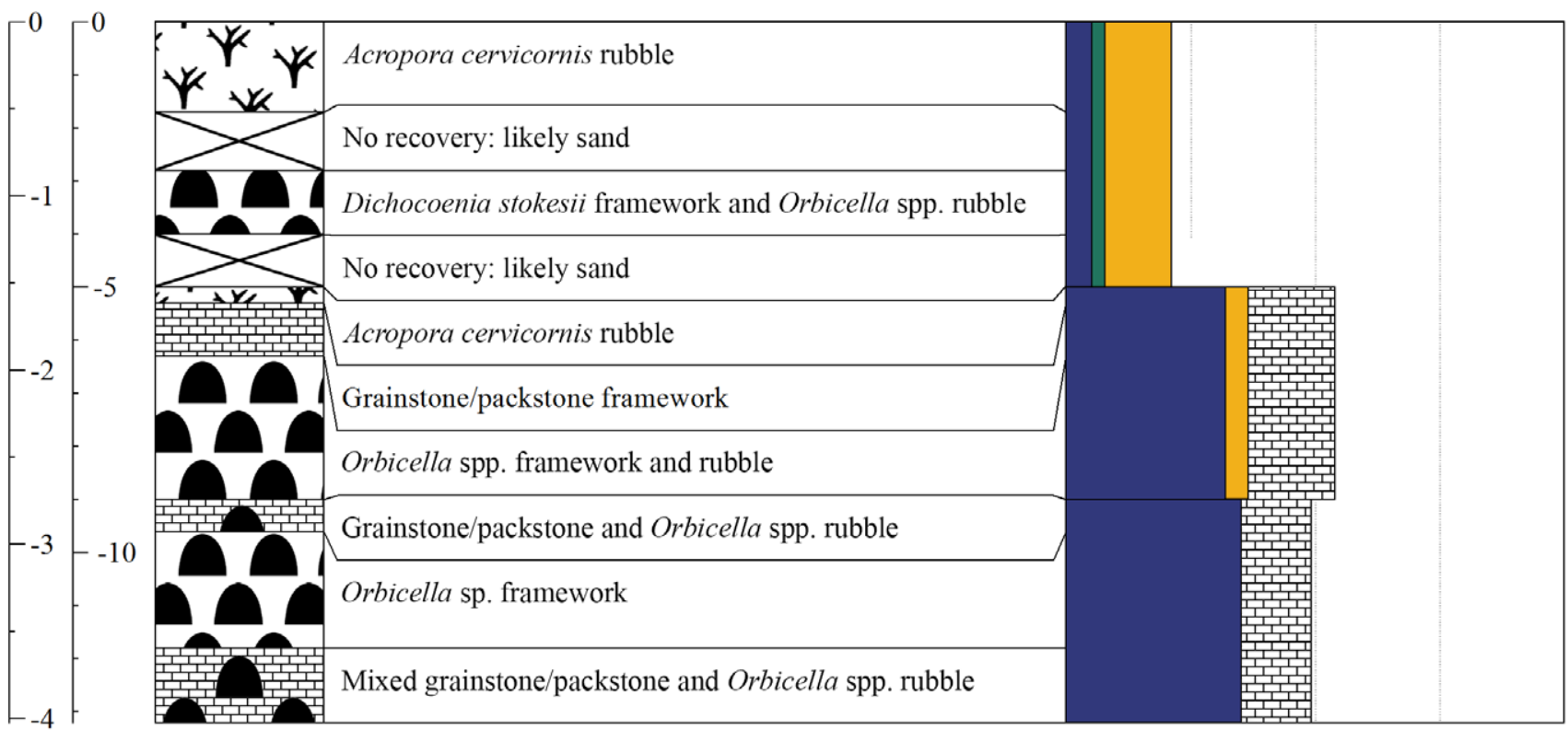

Appendix Figure 12. Descriptive core log for core MK-TN-3. 


\section{Tennessee Reef: MK-TN-4}

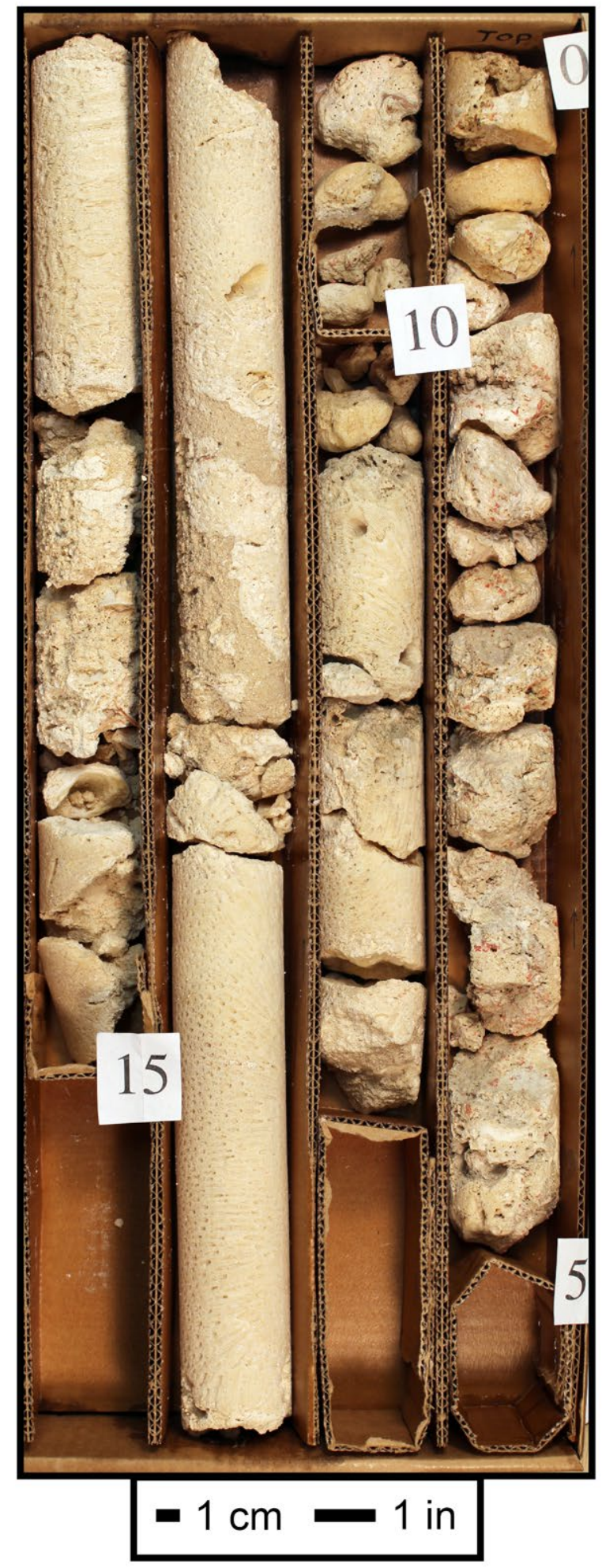

Appendix Figure 13. Photograph of core MK-TN-4. 


\section{CORE NAME:Tennessee Reef \#4 (MK-TN-4)}

Location: Tennessee Reef, Florida Keys National Marine Sanctuary

Drilled By: Toth, L.T.; Stathakopoulos, A.; Reynolds, B.J.; Wilcox, H.

Logged By: Toth, L.T.

Date Cored: 9/9/2015

Water Depth: $20.4 \mathrm{ft}(6.2 \mathrm{~m})$

Latitude: $\quad 24.7454$

Longitude: $\quad-80.7789$

\begin{tabular}{|c|c|c|c|}
\hline 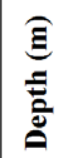 & 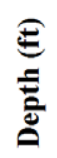 & $\frac{0}{0}$ & Lithologic Description \\
\hline
\end{tabular}

Core Recovery (\%)

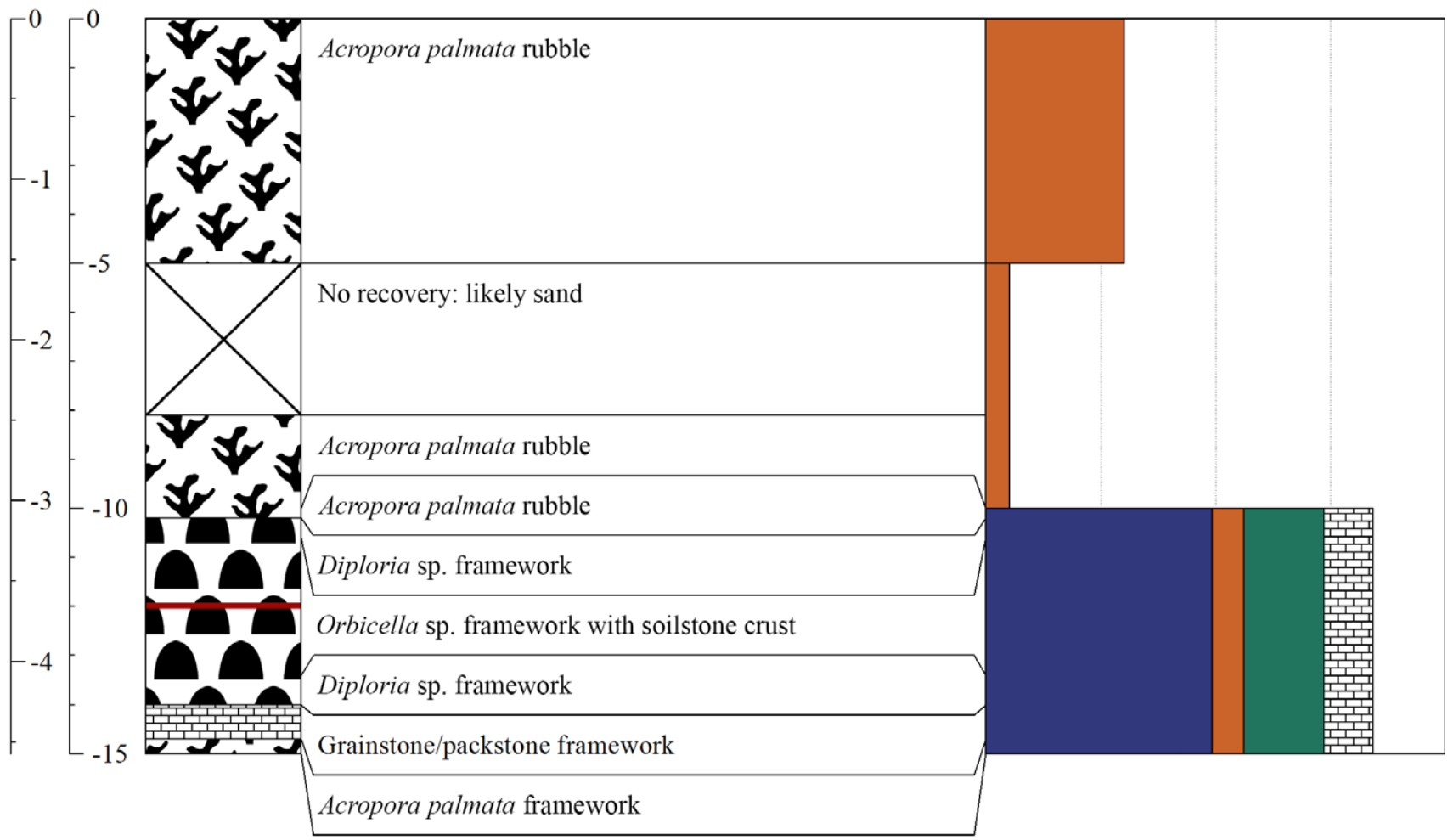

Appendix Figure 14. Descriptive core log for core MK-TN-4. 


\section{Alligator Reef: MK-AR-1A}

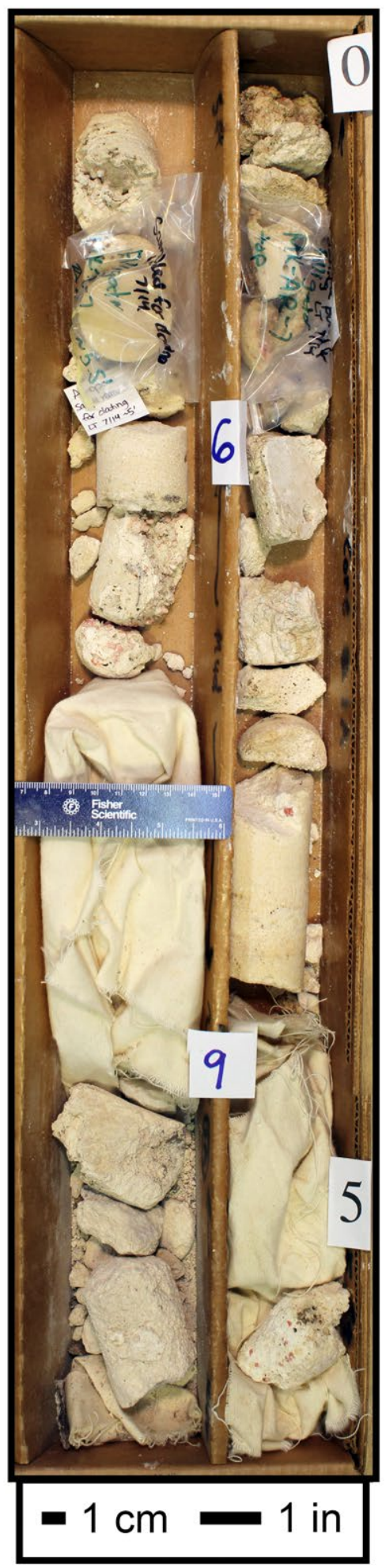

Appendix Figure 15. Photograph of core MK-AR-1A. 


\section{CORE NAME:Alligator Reef \#1A (MK-AR-1A)}

Location: Alligator Reef, Florida Keys National Marine Sanctuary

Drilled By: Robbin, D.M.; J.H. Hudson

Logged By: Toth, L.T.

Date Cored: 7/14/1981

Water Depth: $13.1 \mathrm{ft}(5.0 \mathrm{~m})$

Latitude: 24.8504

Longitude: $\quad-80.6164$

怂

Core Recovery (\%)

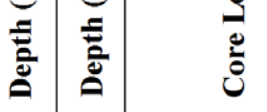

25

50

75

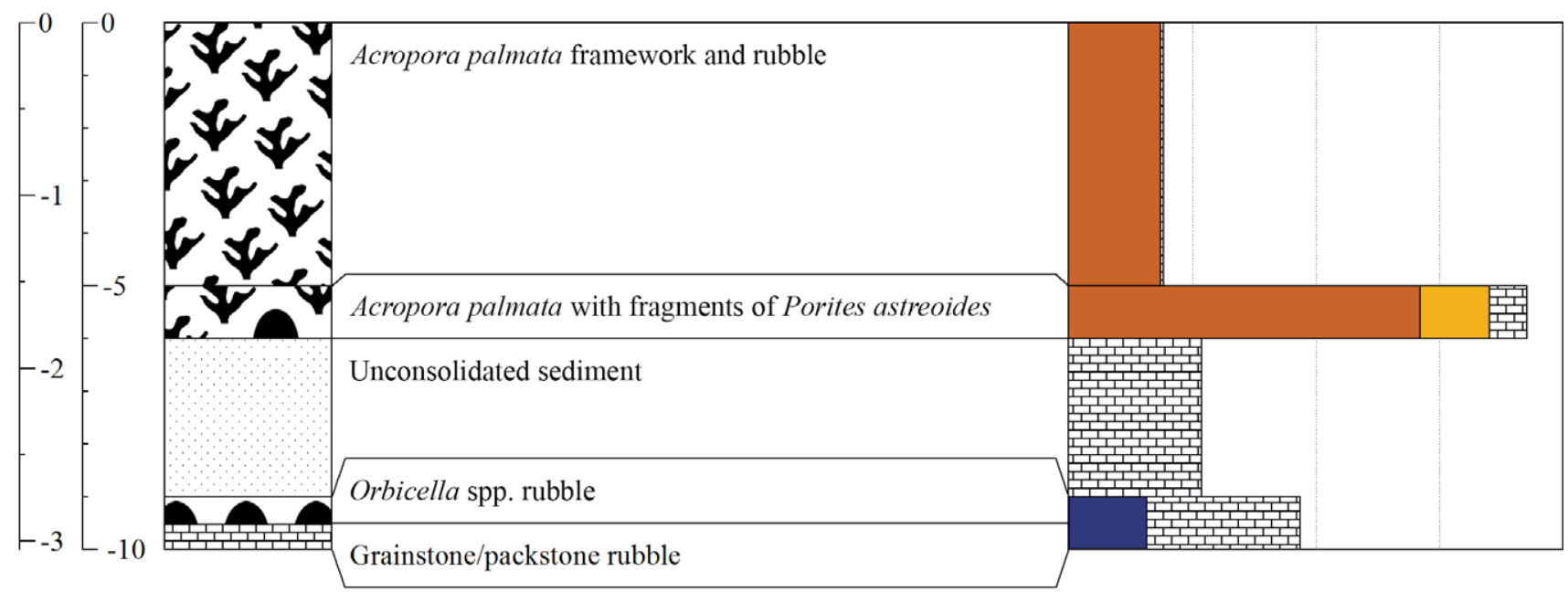

Appendix Figure 16. Descriptive core log for core MK-AR-1A. 


\section{Alligator Reef: MK-AR-2}

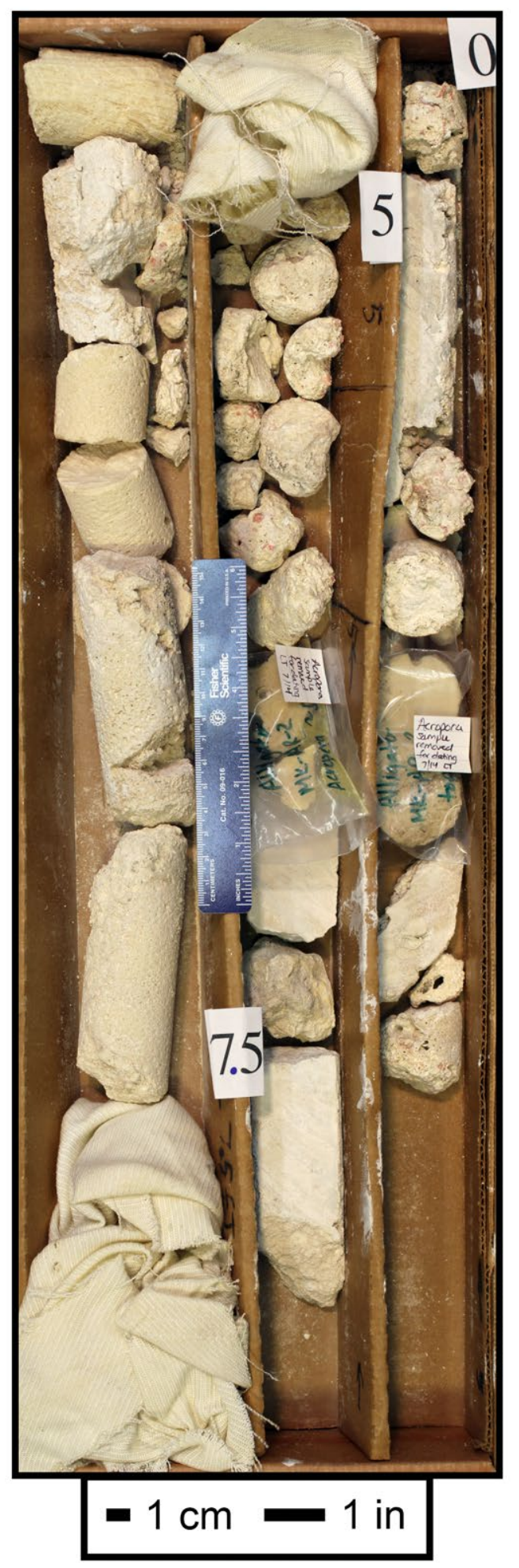

Appendix Figure 17. Photograph of core MK-AR-2. 


\section{CORE NAME:Alligator Reef \#2 (MK-AR-2)}

Location: Alligator Reef, Florida Keys National Marine Sanctuary

Drilled By: Robbin, D.M.; J.H. Hudson

Logged By: Toth, L.T.

Date Cored: $7 / 14 / 1981$

Water Depth: $16.4 \mathrm{ft}(5.0 \mathrm{~m})$

Latitude: $\quad 24.8504$

Longitude: $\quad-80.6164$

ङ

Core Recovery (\%)

紊 竞

25

50

$\mid$\begin{tabular}{lll} 
Grainstone/packstone \\
\hline-2
\end{tabular}

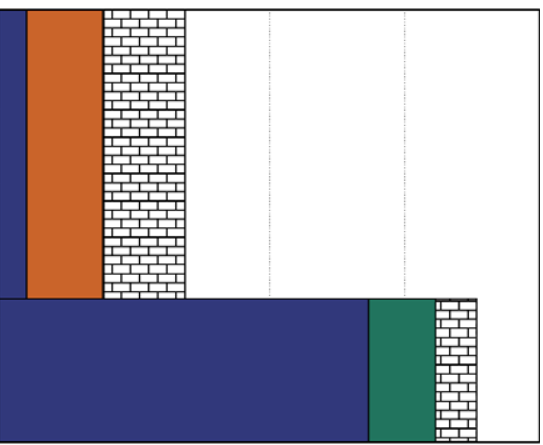

Appendix Figure 18. Descriptive core log for core MK-AR-2. 


\section{Alligator Reef: MK-AR-4}

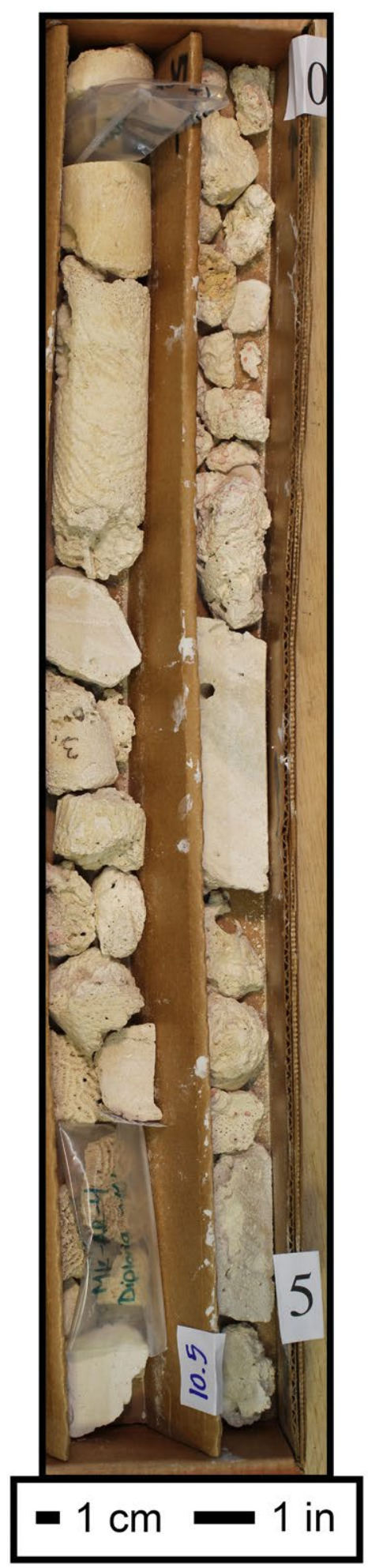

Appendix Figure 19. Photograph of core MK-AR-4. 


\section{CORE NAME:Alligator Reef \#4 (MK-AR-4)}

Location: Alligator Reef, Florida Keys National Marine Sanctuary

Drilled By: Robbin, D.M.; J.H. Hudson

Logged By: Toth, L.T.

Date Cored: $7 / 15 / 1981$

Water Depth: $12.5 \mathrm{ft}(3.8 \mathrm{~m})$

Latitude: 24.8504

Longitude: $\quad-80.6164$

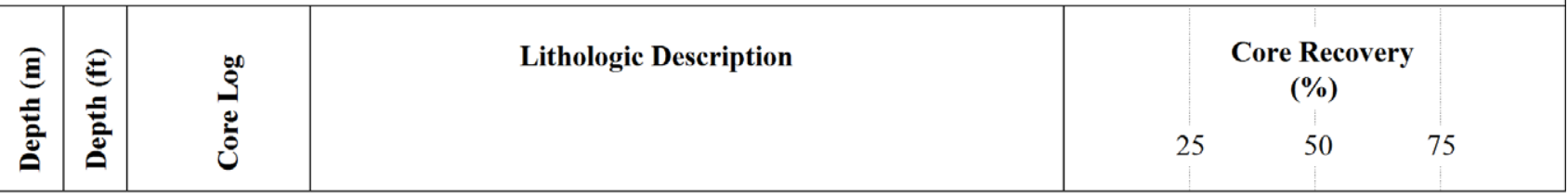

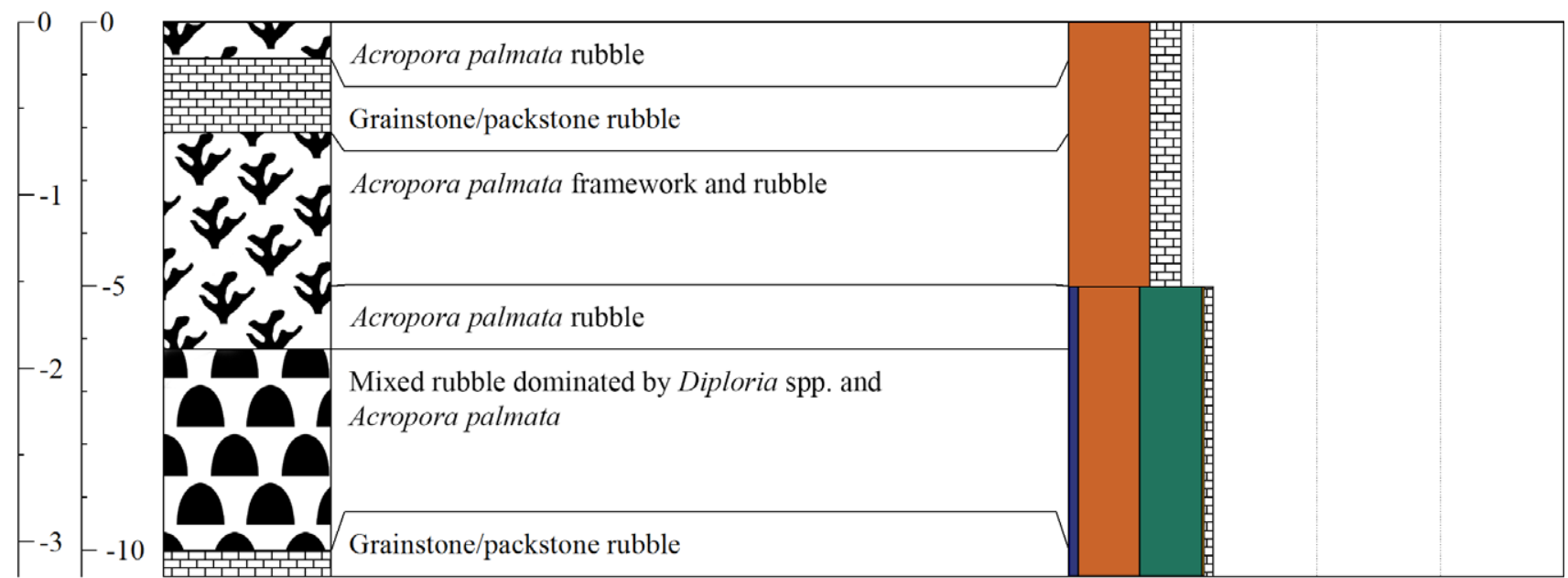

Appendix Figure 20. Descriptive core log for core MK-AR-4. 
ơ

西

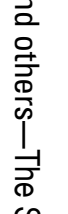

足

क

言

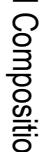

응

일

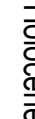

$$
\stackrel{\bigcirc}{\stackrel{\bigcirc}{\mathcal{Q}}}
$$

$\frac{\mathscr{\Phi}}{\pi}$

$\frac{\mathbb{D}}{\mathrm{D}}$

志

$\frac{3}{\bar{z}}$

끔.

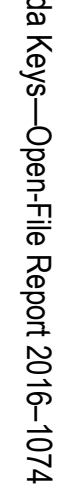

